\title{
Ischemia-modified albumin and the IMA/albumin ratio in the diagnosis and staging of hemorrhagic shock: A randomized controlled experimental study
}

\author{
Süleyman Türedi, M.D., ${ }^{1}$ () Aynur Şahin, M.D., ${ }^{1}$ () Metehan Akça, M.D., ${ }^{2}$ () Selim Demir, M.D., ${ }^{3}$ \\ Gökçen Derya Reis Köse, M.D., ${ }^{4}$ (๑) Arif Burak Çekiç, M.D., ${ }^{5}$ ๑ Mehmet Yıldırım, M.D., ${ }^{2}$

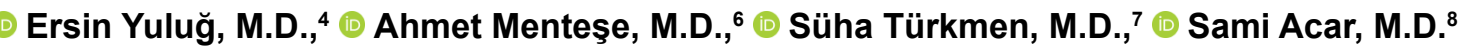

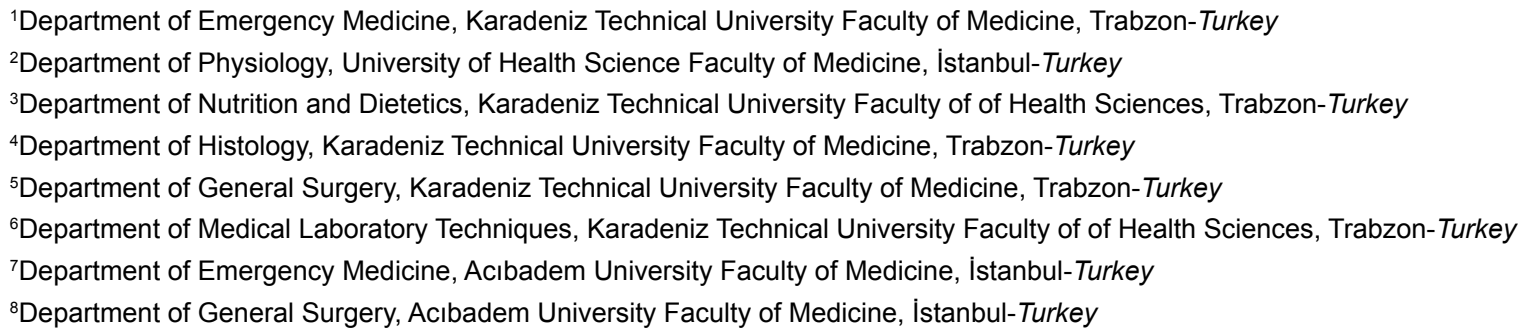

\section{ABSTRACT}

BACKGROUND: To determine the value of ischemia-modified albumin (IMA) and IMA/albumin ratio (IMAR) in the diagnosis and staging of hemorrhagic shock (HS).

METHODS: A pressure-targeted HS model was established in this study. The control and shock groups were monitored for 30 min and $60 \mathrm{~min}$ to simulate varying durations of exposure to HS. All subjects underwent invasive arterial monitoring during the experiment and were further divided into mild and severe shock groups based on decreases in mean arterial pressure (MAP). Biochemical and histologic comparisons were performed between the groups.

RESULTS: Our results revealed higher IMA, IMAR, lactate, total oxidant status (TOS) and oxidative stress index (OSI) levels in both the 30- and 60-min shock groups compared to the control group. Concerning MAP-based shock staging, IMA, IMAR, lactate, TOS and OSI levels in the 30-min and 60-min mild and severe shock groups were higher than those of the controls. However, there was no significant difference between the mild and severe shock groups. A significant correlation was determined between all the biomarkers evaluated and HS-induced damage in various organs. This correlation was highest in lactate and IMAR levels.

CONCLUSION: IMA and IMAR levels may be used in the early diagnosis of HS and also have the potential for use in determining the severity of HS. IMA and IMAR measurement may also be considered as an alternative or in addition to lactate measurement in the diagnosis of HS.

Keywords: Albumin; hemorrhage; ischemia modified albumin; hemorrhagic shock; lactate; trauma.

\section{INTRODUCTION}

\section{Background}

Trauma and trauma-related hemorrhage are one of the main causes of mortality and morbidity in young people world- wide. ${ }^{[l]}$ Significant hemorrhage following trauma progresses rapidly within a few hours, resulting in hemorrhagic shock (HS). The majority of trauma-related mortality is associated with uncontrolled hemorrhage and HS. ${ }^{[2]}$

Cite this article as: Türedi S, Şahin A, Akça M, Demir S, Reis Köse GD, Çekiç AB, et al. Ischemia-modified albumin (IMA) and the IMA/albumin ratio in the diagnosis and staging of hemorrhagic shock: A randomized controlled experimental study. Ulus Travma Acil Cerrahi Derg 2020;26:153-162.

Address for correspondence: Süleyman Türedi, M.D.

Karadeniz Teknik Üniversitesi Tıp Fakültesi, Acil Tıp Anabilim Dalı, 61080 Trabzon, Turkey

Tel: +90 462 - 377 II 6 I E-mail: suleymanturedi@hotmail.com 


\section{Importance}

The identification of hypoperfusion and assessing the degree thereof are of major importance in predicting adverse clinical events that may develop in association with HS and in planning appropriate treatment. Traditional parameters, such as blood pressure (BP), heart rate (HR), and respiration rate (RR), have been used for many years and are still employed as guides for trauma team activation and trauma management. ${ }^{[3,4]}$ The physiological response to hemorrhage is quite variable. Vital parameters alone may be inadequate in the management of HS due to the insidious course of HS from the compensated phase to the decompensated phase and eventually to the irreversible phase, and due to the variation in the physiological response observed during this progression. In addition, more frequent comorbid disease, particularly in elderly patients, use of drugs, such as B-blockers, other accompanying injuries and physiological changes emerging in association with pain, may also lead to confusion in the diagnosis of $\mathrm{HS} .^{[5]}$ In the light of the foregoing, there is a need for more objective criteria or biomarkers that can be used in the early diagnosis of HS, and that are capable of predicting its severity and subsequent prognosis, and of guiding treatment. Lactate, a product of anaerobic metabolism emerging during and after tissue hypoperfusion, is recommended as the most useful biochemical marker in several hypoperfusion states. ${ }^{[6,7]}$ However, various factors affecting lactate levels other than hypoperfusion restrict the diagnostic use of lactate by itself.

Under acute ischemic and hypoxic conditions, the binding capacity of albumin to the metal in the $\mathrm{N}$-terminus region decreases and gives rise to the metabolic protein ischemiamodified albumin (IMA). Previous studies have shown that IMA levels increase rapidly from the onset of ischemic and hypoxic states and are determined at high levels in the blood so long as ischemia is maintained. ${ }^{[8-11]}$

\section{Objectives of This Investigation}

This study aims to determine the value of IMA and IMAR levels in diagnosis and in determining the severity of $\mathrm{HS}$ in an experimentally induced model and to examine the relation with lactate levels.

\section{MATERIALS AND METHODS}

\section{Study Design}

This randomized, controlled, non-blinded experimental study was approved by the Karadeniz Technical University Animal Care and Ethics Committee.

\section{Setting and Selection of the Participants}

The experiments were carried out in the Karadeniz Technical University Experimental Research and Application Center laboratory. Thirty-two mature female Wistar rats weighing
$350 \pm 25 \mathrm{~g}$ were kept in steel cages until the day of the study at a room temperature of $22^{\circ} \mathrm{C}$ and were given water and standard rat chow. For the last 12 hours before the experiment, they were given only water.

\section{Intervention}

HS model: Our review of the literature revealed various different, widely-accepted experimental HS models. The pressure-targeted HS model involves the induction of blood loss until a predetermined pressure is reached. ${ }^{[12-14]}$ In the blood pressure-targeted model, blood loss cannot be standardized, and targeted blood pressure levels may be reached with different amounts of blood loss.

The study groups in this study were classified into a control group with no blood loss and HS groups with target blood pressure. The groups were assessed after 30- and 60-min observation.

To induce HS, general anesthesia was first applied with the intramuscular injection of $90 \mathrm{mg} / \mathrm{kg}$ ketamine and $10 \mathrm{mg} / \mathrm{kg}$ xylazine. The left femoral artery was then cannulated with a $26 \mathrm{G}$ iv cannula under a microscope, under aseptic conditions and with an aseptic technique. All rats were subjected to hemodynamic monitoring throughout the study, and hemodynamic parameters were recorded dynamically. Exsanguination was then performed at a rate of $0.5 \mathrm{cc} / 100 \mathrm{mg} / 2 \mathrm{~min}$ until the desired blood pressure was achieved.

Following these recordings, we observed varying hemodynamic responses despite rats being exposed to similar amounts of blood loss. On the basis of these responses, the shock groups were classified based on the amount of decrease in mean arterial pressure (MAP) levels. Rats with a decrease in MAP $\leq 30 \%$ during this study were classified as the mild shock group and those with a decrease in MAP $>30 \%$ as the severe shock group. Following this classification, our study groups consisted of 30-min control, 30-min mild shock, 30-min severe shock, 60-min control, 60-min mild shock, and 60 -min severe shock groups. All rats were euthanized by decapitation under anesthesia after the prescribed period.

Six groups were established based on hemodynamic responses after blood loss and decreases in MAP levels as follows:

The 30-min control group (Group I): Undergoing anesthesia and iv cannulation, but receiving continuous $30-\mathrm{min}$ hemodynamic monitoring without blood loss, and with blood specimens collected for IMA, albumin and lactate measurement at the end of $30 \mathrm{~min}$.

The 30-min mild shock group (Group II): Exposed to blood loss after anesthesia and iv cannulation. Continuous hemodynamic monitoring was performed for $30 \mathrm{~min}$, with a decrease in MAP $\leq 30 \%$ compared to the initial level. Blood 
specimens were taken for IMA, albumin and lactate measurements after $30 \mathrm{~min}$.

The 30-min severe shock group (Group III): Exposed to blood loss after anesthesia and iv cannulation. Continuous hemodynamic monitoring was performed for $30 \mathrm{~min}$, with a decrease in MAP $>30 \%$ compared to the initial level. Blood specimens were taken for IMA, albumin and lactate measurements after $30 \mathrm{~min}$.

The 60-min control group (Group IV): Undergoing anesthesia and iv cannulation, but receiving continuous 60 min hemodynamic monitoring without blood loss, and with blood specimens collected for IMA, albumin and lactate measurement at the end of $30 \mathrm{~min}$.

The 60-min mild shock group (Group V): Exposed to blood loss after anesthesia and iv cannulation. Continuous hemodynamic monitoring was performed for $60 \mathrm{~min}$, with a decrease in MAP $\leq 30 \%$ compared to the initial level. Blood specimens were taken for IMA, albumin and lactate measurements after $60 \mathrm{~min}$.

The 60-min severe shock group (Group VI): Exposed to blood loss after anesthesia and iv cannulation. Continuous hemodynamic monitoring was performed for $60 \mathrm{~min}$, with a decrease in MAP $>30 \%$ compared to the initial level. Blood specimens were taken for IMA, albumin and lactate measurements after $60 \mathrm{~min}$.

\section{Monitoring and Recording of Hemodynamic Parameters}

Following the completion of femoral artery cannulation, the tip of the 26 Giv cannula was attached to a pressure transducer (Reusable BP Transducer, ADInstruments, Castle Hill, Australia) to measure blood pressure. Once the animals had been placed onto the experimental platform on which physiological parameters were to be recorded, the BP transducer was attached to a blood pressure amplifier (Quad Bridge Amp, ADInstruments, Castle Hill, Australia) with a data acquisition unit (PowerLab 26T, ADInstruments, Castle Hill, Australia), and monitoring and recording were carried out with the help of the computer by which the system was controlled. For ECG recording, ECG gel was applied to the animal's front legs and left rear leg, and ECG Clip electrodes (ADInstruments, Castle Hill, Australia) were then attached. These electrodes were then connected to the data acquisition unit via the amplifier (ADInstruments, Castle Hill, Australia). Respiratory rate was recorded with the help of a piezoelectric transducer (Piezo Electric Pulse Transducer, ADInstruments, Castle Hill, Australia) attached to an elastic strap on the animal's chest. Animals' body temperatures were monitored with a probe throughout the experiments and were maintained at $37^{\circ} \mathrm{C}$ with a homoeothermic blanket system (Harvard Homoeothermic Blanket, Harvard Instru- ments, South Natick, MA, USA). ECG, blood pressure, heart rate and respiratory rate were recorded from rats attached to the electrophysiological data acquisition unit for the time periods determined in the different groups. All parameters were monitored and recorded using LabChart software (v8. I, ADInstruments, Castle Hill, Australia). During the recording, baseline ECG, blood pressure and respiratory data were first collected for $10 \mathrm{~min}$, and the hemorrhagic shock model was then established without interrupting the recording. Once the model had been established, data recording was carried out for the specified 30 - or 60 -min periods. At the end of the experiment, the ECG, blood pressure and respiratory rate data obtained were converted into numerical values with the help of LabChart software modules.

\section{Biochemical Measurements}

At the end of this study, IMA, albumin and lactate measurements were carried out with blood collection from the femoral artery to induce HS.

In addition to serum IMA, IMAR and lactate levels, we also evaluated TAS, TOS and OSI levels, which play roles in ischemic-hypoxic pathophysiology and reflect oxidant and antioxidant status. All parameters were measured by a biochemist blinded to the different animal group.

IMA and IMAR measurement: Serum and plasma samples were prepared with 15 min of centrifugation at 3000 $\mathrm{rpm}$. The specimens were pipetted into Eppendorf tubes and stored at $-80^{\circ} \mathrm{C}$. Reduced cobalt to albumin binding capacity (IMA level) was analyzed using the rapid and colorimetric method and the results were reported as absorbance units (ABSUs) (8). Serum albumin levels were estimated using an automated analyzer, Cobas 6000 (Roche, Germany). IMAR levels were calculated as a ratio of IMA to albumin, and the results were expressed as $\mu \mathrm{g} /$ per $\mathrm{g}$ albumin.

Lactate measurement: Lactate measurement was performed using a Roche vitreous chemistry 950 autoanalyzer.

TAS, TOS, and OSI measurement: TAS in tissue was measured using an automated colorimetric measurement method. ${ }^{[15]}$ TOS was determined using an automated measurement method. ${ }^{[16]}$ Serum TAS levels were calculated in mmol Trolox equivalent/L. Serum TOS levels were calculated in $\mu \mathrm{mol} \mathrm{H} 2 \mathrm{O} 2$ equivalent/L. The TOS/TAS ratio was used as the oxidative stress index (OSI). To perform that calculation, the TAS unit, mmol Trolox equivalent/L, was converted to mmol Trolox equivalent/L, and OSI was calculated as follows using the formula OSI $=[(\mathrm{TOS}, \mu \mathrm{mol} \mathrm{H} 2 \mathrm{O} 2$ equivalent/L)/ (TAS, $\mu \mathrm{mol}$ Trolox equivalent/L) $\times 100]$.

\section{Histopathological Examination}

Following blood sampling and euthanasia by decapitation, heart, brain, small bowel, liver and striated muscle specimens 
were collected for histopathological examination. All samples were macro- and microscopically evaluated by a histologist blinded to which groups animals belonged.

At brain damage analysis, all layers of the cortex were assessed concerning general histological architecture. The cortex regions of both hemispheres were classified histologically about neuronal changes: Grade I; mildly shrunken neurons with/without cytoplasmic vacuolization, Grade 2; moderately shrunken neurons (eosinophilic cytoplasm), and increased nuclear basophilia or vacuolated cytoplasm and vesicular nuclei, Grade 3; severely shrunken neurons (eosinophilic cytoplasm), pyknotic nuclei. In addition, the percentage of degenerative pyramidal neurons was calculated by counting 100 pyramidal cells in the cortex at $\times 200$ magnification on Analysis 5 Research software (OlympusSoftlmaging Solutions, Münster, Germany). ${ }^{[8]}$

At heart damage analysis, myocardial cell degeneration in heart tissue myocardial fibrosis and vascular damage were assessed using a semi-quantitative method. Myocardial cell degeneration was scored between 0 and 3; 0 (normal): no degeneration in myocytes, I (mild): A few degenerated myocytes, 2 (moderate): approximately $50 \%$ myocyte degeneration, and 3 (severe): myocyte degeneration exceeding $50 \% .{ }^{[17]}$

Kidney damage was assessed using the semi-quantitative method concerning degeneration in tubular cells and intertubular vascular congestion, scored between 0 and 3 as follows; 0: none, I: mild, 2: moderate, and 3: severe. For scoring, preparates were evaluated by inspecting 20 different areas at x200 magnification. Damage assessment was based on the cortex and extramedullary areas. Degeneration in tubular cells was assessed concerning dilatation, shedding and vacuolization in tubular epithelial cells, and scored. ${ }^{[18]}$

At examination of bowel damage, the ilium was sampled, and each area was scored between 0 and 3 using the semi-quantitative method concerning inflammatory cell infiltration, hemorrhage, villus conglomeration, and epithelial degeneration in the apical surface of the villus; 0 : none; I: mild; 2 : moderate, and 3: severe. ${ }^{[1]}$

At the analysis of liver damage, five randomly selected different areas in preparates from all groups were assessed concerning general histological architecture. Every tissue specimen was assessed semi-quantitatively in hepatocyte degeneration, vascular congestion, sinusoidal dilatation and congestion in vacuolated sinusoids using the scale 0 : none; I: mild, 2: moderate, and 3: severe. ${ }^{[19]}$

At striated muscle evaluation, disorganization in muscle fibers was assessed semi-quantitatively concerning inflammatory cell infiltration using scale 0 : normal, I: mild, 2: moderate, and 3: severe. ${ }^{[20]}$

\section{Outcome Measures}

The primary outcome was the determination of any differences concerning serum IMA, IMAR, lactate, TOS, TAS and OSI values in the groups exposed to HS of varying severity according to scores based on decreases in MAP, and of correlation between lactate levels and IMA and IMAR levels, the most frequently used biochemical parameters in the monitoring and treatment of HS in clinical practice, and between HS-related histological damage and IMA, lactate and IMAR values.

\section{Statistical Analysis}

Statistical analysis was performed using SPSS 23.0 (IBM SPSS Statistics, IBM Corporation, Armonk, NY) and MedCalc 12.3 (MedCalc Software, Mariakerke, Belgium). Results were expressed as median and 25-75 percentiles. Multiple group comparisons between groups with mild and severe shock based on decreases in MAP and the control groups were performed using Kruskal Wallis analysis of variance (Mann-Whitney $U$ test with Bonferroni correction as post hoc). Spearman's correlation analysis was used to assess the relationship between biochemical parameters and histopathological damage scores. Statistical significance was set at $p<0.05$.

\section{RESULTS}

\section{i. Biochemical Parameters}

Serum IMA, lactate and IMAR levels determined in the different groups at the analysis of the mild and severe shock groups based on decreases in MAP and comparisons between the groups are shown in Table I.

As shown in Table I, IMA, IMAR, lactate, TOS and OSI values in the mild and severe shock groups constituted on the basis of MAP were higher than those in the control groups. However, no significant difference was determined between the mild and severe shock groups concerning IMA, IMAR, lactate, TOS, or OSI. Only TOS values were significantly higher in the severe shock group compared to the mild shock group.

\section{ii. Histopathological Examination}

Histopathological findings of organ damage determined in the mild and severe shock groups established on the basis of decreases in MAP levels and comparisons between the groups are shown in Table 2.

As shown in Table 2, damage in the control group was lower than in the mild and severe shock groups classified according to MAP. However, damage levels in the mild and severe shock groups were similar.

\section{iii. Correlation Results}

Correlation results between the biomarkers assessed and HSrelated histopathological damage in different organs are shown 
Table I. A comparison of biochemical measurements between the mild and severe HS groups based on decreases in MAP, and the control group

\begin{tabular}{|c|c|c|c|c|c|c|c|}
\hline \multirow[b]{2}{*}{ Parameters } & \multicolumn{3}{|c|}{ 30-min observation } & \multicolumn{3}{|c|}{ 60-min observation } & \multirow[t]{2}{*}{$\mathbf{p}^{*}$} \\
\hline & $\begin{array}{l}\text { Group I } \\
30 \text { min } \\
\text { control } \\
(n=5)\end{array}$ & $\begin{array}{c}\text { Group II } \\
30 \text { min } \\
\text { mild shock } \\
(n=5)\end{array}$ & $\begin{array}{c}\text { Group III } \\
30 \text { min } \\
\text { severe shock } \\
(n=5)\end{array}$ & $\begin{array}{l}\text { Group IV } \\
60 \text { min } \\
\text { control } \\
(n=5)\end{array}$ & $\begin{array}{c}\text { Group V } \\
60 \text { min } \\
\text { mild shock } \\
(n=5)\end{array}$ & $\begin{array}{c}\text { Group VI } \\
60 \text { min } \\
\text { severe shock } \\
(n=7)\end{array}$ & \\
\hline \multicolumn{8}{|l|}{ IMA (ABSU) } \\
\hline Median & 0.681 & 0.747 & 0.746 & $0.644^{a, b}$ & $0.755^{\mathrm{a}}$ & $0.739^{\mathrm{b}}$ & $=0.026^{\mathrm{a}}$ \\
\hline Percentiles (25-75) & $0.614-0.708$ & $0.688-0.763$ & $0.728-0.796$ & $0.610-0.688$ & $0.695-0.806$ & $0.700-0.826$ & $=0.012^{b}$ \\
\hline IMAR (mg/per g albumin) & & & & & & & $=0.016^{\mathrm{a}, \mathrm{b}}$ \\
\hline Median & $0.25^{\mathrm{a}}$ & $0.34^{a}$ & $0.35^{\mathrm{b}}$ & $0.23^{c, d}$ & $0.30^{c}$ & $0.32^{d}$ & $=0.009 c$ \\
\hline Percentiles $(25-75)$ & $0.264-0.30$ & $0.31-0.38$ & $0.33-0.41$ & $0.22-0.27$ & $0.29-0.37$ & $0.30-0.38$ & $=0.004^{\mathrm{d}}$ \\
\hline Lactate (mg/dl) & & & & & & & $=0.009^{a}$ \\
\hline Median & $8.65^{\mathrm{a}}$ & 22.49 & $23.99^{a}$ & $7.49^{b}$ & 23.92 & $27.74^{b}$ & $=0.004^{\mathrm{b}}$ \\
\hline Percentiles (25-75) & $4.98-10.48$ & 13.59-26.82 & $18.64-28.42$ & $6.68-15.37$ & $13.94-53.04$ & $23.03-34.02$ & \\
\hline TAS (mmoltrolox equivalent/L) & & & & & & & $=0.009^{\mathrm{a}}$ \\
\hline Median & $1.26^{\mathrm{a}, \mathrm{b}}$ & $0.67^{a}$ & $0.40^{\mathrm{b}}$ & $1.07^{\mathrm{c}}$ & 0.56 & $0.59^{c}$ & $=0.016^{\mathrm{b}}$ \\
\hline Percentiles (25-75) & $1.10-1.58$ & $0.43-0.76$ & $0.35-0.83$ & $0.94-1.28$ & $0.55-0.91$ & $0.38-0.71$ & $=0.004^{c}$ \\
\hline TOS ( $\mu \mathrm{mol} \mathrm{H} 2 \mathrm{O} 2$ equivalent/L) & & & & & & & $=0.009^{a, b, c}$ \\
\hline Median & $2.66^{a, b}$ & $8.63^{a}$ & $8.7 I^{b}$ & $3.44^{c, d}$ & $\left.8.4\right|^{c, e}$ & $9.40^{\mathrm{d}, \mathrm{e}}$ & $=0.004^{d}$ \\
\hline Percentiles (25-75) & $2.49-3.38$ & $8.16-8.92$ & $8.17-9.07$ & $2.23-5.36$ & $8.17-8.68$ & $8.89-9.60$ & $=0.007^{\mathrm{e}}$ \\
\hline OSI & & & & & & & $=0.009^{a, b, c}$ \\
\hline Median & $0.22^{\mathrm{a}, \mathrm{b}}$ & $1.23^{\mathrm{a}}$ & $2.0 \mathrm{I}^{\mathrm{b}}$ & $0.32^{\mathrm{c}, \mathrm{d}}$ & $1.49^{c}$ & $1.6 \mathrm{I}^{\mathrm{d}}$ & $=0.004^{\mathrm{d}}$ \\
\hline Percentiles $(25-75)$ & $0.16-0.29$ & $\mathrm{I} .1 \mathrm{I}-2.54$ & I.13-2.42 & $0.24-0.41$ & $0.99-|.5|$ & $1.26-2.33$ & \\
\hline
\end{tabular}

IMA: Ischemia modified albumin; IMAR: IMA/albumin ratio; TAS: Total antioxidant status; TOS: Total oxidant status; OSI: Oxidative stress index. *According to Kruskal Wallis variance analysis (the Mann-Whitney $U$ test with Bonferroni correction as post hoc).

in Table 3. Our findings revealed a significant correlation between all the markers investigated (IMA, IMAR, lactate, TOS, TAS and OSI) and HS-related damage in different tissues. This correlation was highest in lactate and IMAR values.

Correlations within biochemical parameters are shown in Table 4. Our findings revealed a moderately significant positive correlation between lactate values and IMA and IMAR.

\section{DISCUSSION}

Early determination and appropriate treatment of trauma-related hemorrhage and $\mathrm{HS}$ represent the fundamental principle of HS management. To our knowledge, our study is the first study to examine the value of levels of the novel biomarkers IMA and IMAR, already shown to increase in blood under acute ischemic and hypoxic conditions, in the diagnosis of HS and the determination of its severity. According to the results of this preliminary study, IMA and IMAR values follow a similar course to those of lactate, which is still used in the diagnosis and management of treatment of HS and other form of shock, particularly septic shock. From that perspective, IMA and IMAR levels have the potential for use in the early diagnosis of HS, in determining the severity of HS and as a prognostic marker.

The first step in the management of shock in trauma, one of the leading causes of death in young people, is to identify the presence of shock. The probable cause of shock then needs to be determined and treated accordingly. Trauma management guidelines today still recommend the use of scoring based on the physiological response to hemorrhage and the clinical findings that result in the diagnosis of HS and in staging its severity. Although this physiological classification system assists the diagnosis and management of HS, several factors may nevertheless cause variations in the physiological response, and can, therefore, lead to errors in the diagnosis and classification of HS based on it..$^{[3]}$ This is because these traditional hemodynamic parameters, such as blood pressure, heart rate and urine output, are inadequate indicators of end-organ hypoperfusion. Classic parameters, such as blood pressure and saturation, have been determined as normal in approximately $20 \%$ of the patients with HS. Vital signs are insufficient in the decision to safely conclude resuscitation of patients with $\mathrm{HS}$, as they are in the diagnosis of shock and determining its depth. 
Table 2. A comparison of histopathological measurements between the mild and severe HS groups based on decreases in MAP, and the control group

\begin{tabular}{|c|c|c|c|c|c|c|c|}
\hline \multirow[b]{2}{*}{ Parameters } & \multicolumn{3}{|c|}{ 30-min observation } & \multicolumn{3}{|c|}{ 60-min observation } & \multirow[t]{2}{*}{$\mathbf{p}^{*}$} \\
\hline & $\begin{array}{l}\text { Group I } \\
30 \text { min } \\
\text { control } \\
(n=5)\end{array}$ & $\begin{array}{c}\text { Group II } \\
30 \text { min } \\
\text { Mild shock } \\
(n=5)\end{array}$ & $\begin{array}{c}\text { Group III } \\
30 \text { min } \\
\text { Severe shock } \\
(n=5)\end{array}$ & $\begin{array}{l}\text { Group IV } \\
60 \text { min } \\
\text { control } \\
(n=5)\end{array}$ & $\begin{array}{l}\text { Group V } \\
60 \text { min } \\
\text { Mild shock } \\
(n=5)\end{array}$ & $\begin{array}{c}\text { Group VI } \\
60 \text { min } \\
\text { Severe shock } \\
(n=7)\end{array}$ & \\
\hline \multicolumn{8}{|l|}{ Degenerative neuron } \\
\hline \multicolumn{8}{|l|}{ percentage (\%) } \\
\hline Median & $12.0^{\mathrm{a}, \mathrm{b}}$ & $43.0^{\mathrm{a}}$ & $39.0^{\mathrm{b}}$ & $12.0^{\mathrm{c}, \mathrm{d}}$ & $42.0^{c}$ & $48.0^{d}$ & $=0.009^{a, b, c}$ \\
\hline Percentiles (25-75) & $9.5-14.0$ & $38.5-58.0$ & $35.0-60.0$ & $11.0-13.5$ & $22.5-50.0$ & $35.0-55.0$ & $=0.004^{d}$ \\
\hline \multicolumn{8}{|l|}{ Total cerebral damage (point) } \\
\hline Median & 1.0 & 2.0 & 1.0 & 1.0 & 2.0 & 2.0 & \\
\hline Percentiles (25-75) & $0.0-1.0$ & $1.0-2.0$ & $1.0-2.5$ & $0.0-1.0$ & $1.0-2.0$ & $1.0-2.0$ & \\
\hline Total cardiac damage (point) & & & & & & & $=0.01 \mathrm{I}^{\mathrm{a}}$ \\
\hline Median & $0.0^{a, b}$ & $5.0^{\mathrm{a}}$ & $4.0^{\mathrm{b}}$ & $0.0^{\mathrm{c}, \mathrm{d}}$ & $4.0^{c}$ & $4.0^{d}$ & $=0.007^{\mathrm{b}}$ \\
\hline \multirow[t]{2}{*}{ Percentiles (25-75) } & $0.0-1.5$ & $2.5-5.5$ & $3.5-5.0$ & $0.0-1.5$ & $4.0-4.0$ & $3.0-4.0$ & $=0.005^{c}$ \\
\hline & & & & & & & $=0.004^{d}$ \\
\hline \multicolumn{8}{|l|}{ Total liver damage (point) } \\
\hline Median & 1.0 & 4.0 & 4.0 & $1.0^{\mathrm{a}, \mathrm{b}}$ & $6.0^{\mathrm{a}}$ & $5.0^{\mathrm{b}}$ & $=0.012^{\mathrm{a}}$ \\
\hline Percentiles (25-75) & $0.5-2.5$ & I.0-7.5 & $2.0-4.0$ & $0.5-3.0$ & $4.5-7.5$ & $3.0-6.0$ & $=0.014^{\mathrm{b}}$ \\
\hline Total kidney damage (point) & & & & & & & $=0.013^{\mathrm{a}}$ \\
\hline Median & $0.0^{a, b}$ & $3.0^{\mathrm{a}}$ & $5.0^{\mathrm{b}}$ & $1.0^{\mathrm{c}, \mathrm{d}}$ & $3.0^{c}$ & $3.5^{\mathrm{d}}$ & $=0.007^{\mathrm{b}}$ \\
\hline \multirow[t]{2}{*}{ Percentiles (25-75) } & $0.0-2.0$ & $3.0-6.0$ & $3.5-5.0$ & $0.0-2.0$ & $2.5-4.5$ & $2.75-4.0$ & $=0.014^{c}$ \\
\hline & & & & & & & $=0.009^{d}$ \\
\hline \multicolumn{8}{|l|}{ Total striated muscle } \\
\hline damage (point) & & & & & & & $=0.007^{\mathrm{a}}$ \\
\hline Median & $0.0^{\mathrm{a}, \mathrm{b}}$ & $3.0^{\mathrm{a}}$ & $5.0^{\mathrm{b}}$ & $1.0^{c, d}$ & $5.0^{c}$ & $5.0^{\mathrm{d}}$ & $=0.008^{b, c}$ \\
\hline Percentiles (25-75) & $0.0-2.0$ & $3.0-5.5$ & $4.0-5.5$ & $0.0-2.0$ & $4.5-6.0$ & $5.0-7.0$ & $=0.004^{d}$ \\
\hline \multicolumn{8}{|l|}{ Total intestinal damage (point) } \\
\hline Median & 1.0 & 3.0 & 3.0 & $2.0^{a, b}$ & $6.0^{\mathrm{a}}$ & $10.0^{\mathrm{b}}$ & $=0.007^{a}$ \\
\hline Percentiles (25-75) & $0.5-2.0$ & $0.5-6.0$ & $2.0-4.0$ & $1.5-2.5$ & $6.0-9.5$ & $8.0-10.0$ & $=0.004^{\mathrm{b}}$ \\
\hline
\end{tabular}

*According to Kruskal Wallis variance analysis (the Mann-Whitney U test with Bonferroni correction as post hoc). HS: Hemorrhagic shock; MAP: Mean arterial pressure.

[21] Inadequate tissue hypoperfusion may be present despite normal physiological parameters. This occult shock is known as cryptic shock and is associated with increased mortality. ${ }^{[22]}$ The majority of trauma patients may maintain normal physiology despite being in critical hypovolemic shock associated with blood loss, and classic hemodynamic parameters may be within normal limits. ${ }^{[23]}$ More sensitive indicators are therefore needed. It has been suggested that biochemical parameters, such as $\mathrm{pH}, \mathrm{PO}_{2}, \mathrm{PCO}_{2}$, and alkali deficit with arterial blood gas measurements in addition to physiological evaluations, can provide more objective diagnostic data, although the most widely employed metabolic parameter is lactate. ${ }^{[24-27]}$

Lactate is a biomarker resulting from oxygen delivery being inadequate to meet metabolic needs and is used as a marker of tissue hypoxia. ${ }^{[28]}$ When a decrease in oxygen delivery due to hypoxia or hypoperfusion exceeds the critical threshold, aerobic metabolism is replaced by anaerobic metabolism, which manifests with lower ATP production and increased lactate. Lactate levels are therefore described as a guide in the diagnosis and treatment of HS, marked by tissue hypoperfusion and hypoxia. Evaluations performed in the light of the current data have shown that both lactate and the normalization of lactate can be used as an indicator of appropriate resuscitation of shock patients in the emergency department. ${ }^{[6,23]}$

Although increased lactate levels and lactic acidosis most commonly derive from hypoxia and hypovolemia and tissue hypoperfusion resulting from these (type A lactate produc- 
Table 3. Correlation results between biochemical parameters and histological damage

\begin{tabular}{|c|c|c|c|c|c|c|c|c|c|c|c|c|c|c|}
\hline & \multicolumn{2}{|c|}{$\begin{array}{c}\text { Degenerative } \\
\text { neuron } \\
\text { percentage }\end{array}$} & \multicolumn{2}{|c|}{$\begin{array}{l}\text { Cerebral } \\
\text { damage }\end{array}$} & \multicolumn{2}{|c|}{$\begin{array}{l}\text { Cardiac } \\
\text { damage }\end{array}$} & \multicolumn{2}{|c|}{$\begin{array}{c}\text { Liver } \\
\text { damage }\end{array}$} & \multicolumn{2}{|c|}{$\begin{array}{l}\text { Kidney } \\
\text { damage }\end{array}$} & \multicolumn{2}{|c|}{$\begin{array}{l}\text { Muscle } \\
\text { damage }\end{array}$} & \multicolumn{2}{|c|}{$\begin{array}{l}\text { Intestinal } \\
\text { damage }\end{array}$} \\
\hline & $r$ & $\mathbf{p}$ & $r$ & $\mathbf{p}$ & $r$ & $\mathbf{p}$ & $r$ & $\mathbf{p}$ & $r$ & $\mathbf{p}$ & $r$ & $\mathbf{p}$ & $r$ & $\mathbf{p}$ \\
\hline IMA & 0.495 & 0.004 & $0.47 I$ & 0.007 & 0.618 & $<0.001$ & 0.208 & 0.254 & 0.469 & 0.008 & 0.491 & 0.004 & 0.243 & 0.181 \\
\hline IMAR & 0.663 & $<0.001$ & 0.591 & $<0.001$ & 0.635 & $<0.001$ & 0.357 & 0.045 & 0.648 & $<0.001$ & 0.580 & $<0.001$ & 0.275 & 0.127 \\
\hline Lactate & 0.727 & $<0.001$ & 0.602 & $<0.001$ & 0.590 & $<0.001$ & 0.566 & $<0.001$ & 0.635 & $<0.001$ & 0.716 & $<0.001$ & 0.511 & $<0.001$ \\
\hline TAS & -0.550 & $<0.001$ & -0.406 & 0.02 & -0.602 & $<0.001$ & -0.451 & 0.01 & -0.563 & $<0.001$ & -0.764 & $<0.001$ & -0.515 & $<0.001$ \\
\hline TOS & 0.658 & $<0.001$ & 0.490 & 0.004 & 0.575 & $<0.001$ & 0.560 & $<0.001$ & 0.537 & 0.002 & 0.693 & $<0.001$ & 0.703 & $<0.001$ \\
\hline OSI & 0.660 & $<0.001$ & 0.503 & 0.003 & 0.633 & $<0.001$ & 0.521 & 0.002 & 0.591 & $<0.001$ & 0.808 & $<0.001$ & 0.591 & $<0.001$ \\
\hline
\end{tabular}

IMA: Ischemia modified albumin; IMAR: IMA/albumin ratio; TAS: Total antioxidant status; TOS: Total oxidant status; OSI: Oxidative stress index. According to Spearman's correlation analysis.

Table 4. Correlation results among biochemical parameters

\begin{tabular}{|c|c|c|c|c|c|c|c|c|c|c|}
\hline & \multicolumn{2}{|c|}{ IMAR } & \multicolumn{2}{|c|}{ Lactate } & \multicolumn{2}{|c|}{ TAS } & \multicolumn{2}{|c|}{ TOS } & \multicolumn{2}{|c|}{ OSI } \\
\hline & $r$ & $\mathbf{p}$ & $\mathbf{r}$ & $\mathbf{p}$ & $r$ & $\mathbf{p}$ & $r$ & $\mathbf{p}$ & $r$ & $\mathbf{p}$ \\
\hline IMA & 0.794 & 0.004 & 0.496 & 0.004 & -0.415 & 0.018 & 0.452 & 0.009 & 0.445 & 0.011 \\
\hline IMAR & & & 0.560 & $<0.001$ & -0.575 & $<0.001$ & 0.506 & 0.003 & 0.581 & $<0.001$ \\
\hline Lactate & & & & & -0.606 & $<0.001$ & 0.643 & $<0.001$ & 0.682 & $<0.001$ \\
\hline TAS & & & & & & & -0.585 & $<0.001$ & -0.941 & $<0.001$ \\
\hline TOS & & & & & & & & & 0.745 & $<0.001$ \\
\hline
\end{tabular}

IMA: Ischemia modified albumin; IMAR: IMA/albumin ratio; TAS: Total antioxidant status; TOS: Total oxidant status; OSI: Oxidative stress index. According to Spearman's correlation analysis.

tion), there are many other causes of lactate elevation that do not involve tissue hypoxia (type B lactate production). Diabetes and drugs, such as metformin used in the treatment of diabetes, leukemia, neoplastic conditions, such as lymphoma or, rarely, some solid tumors, alcohol consumption and chronic alcoholism frequently seen in traffic accident victims, HIV infections and the use of drugs, such as B adrenergic agonists, can all increase lactate levels and cause lactic acidosis. ${ }^{[28]}$ Clinicians managing HS patients should, therefore, consider several conditions capable of resulting in increased lactate levels and must evaluate various potential causes of lactate elevation other than HS. Although lactate is a very useful biomarker from that perspective, new biomarkers capable of use with it are needed in the management of trauma patients. The present study, therefore, considered the novel biomarkers IMA and IMAR for that purpose.

On the basis of our findings, the course of IMA and IMAR values in rats exposed to $H S$ is similar to that of lactate. A significant increase was observed, similar to that in lactase, in the first $30 \mathrm{~min}$ in rats subjected to HS. This increase is significantly positively correlated with HS-related damage occurring in different organs. To our knowledge, this is the first study to reveal an association between IMA and IMAR and $\mathrm{HS}$, and we think that it will serve as a guide for future studies on the subject. Our findings indicate a significant correlation between serum IMA and IMAR values and lactate levels. From that perspective, these may be considered as a novel biomarker capable of use in the diagnosis and measurement of HS together with lactate, or as an alternative to lactate in conditions that may have an effect on lactate levels and in which lactate levels cannot, therefore, be used safely. During acute ischemic and hypoxic conditions, the metal binding capacity of albumin is modified and reduces transition metal binding, generating a metabolic variant of protein. This change is quantifiable and commonly known as IMA. IMA levels can be affected by serum albumin levels. Recent studies involving IMA have, therefore, reported the use of IMA levels, not alone, but in combination with serum albumin levels, or IMAR levels alone are used instead of serum IMA levels. ${ }^{[29]}$ IMA and IMAR levels increase in several conditions involving exposure to hypoxia or ischemia independently of the organ affected. An increase in IMA levels has previously 
been reported in conditions, particularly involving myocardial ischemia, such as acute coronary syndromes, ischemic conditions, such as acute mesenteric ischemia and stroke, and in conditions involving hypoxia, rather than ischemia, such as pulmonary embolism and carbon monoxide intoxication, and evidence exists that this increase can be used for diagnostic and prognostic purposes. ${ }^{[8-1 I]} \mathrm{HS}$ is one of the conditions in which ischemic pathogenesis is most prominent due to decreasing blood volume and also hypoxic pathogenesis in which oxygen delivery is affected by decreasing hemoglobin concentrations. From that perspective, it is logical to expect serum IMA and IMAR values to rise in patients with $\mathrm{HS}$, and it may be concluded that this elevation may potentially be used for diagnostic purposes and has the same potential as lactate clearance in evaluating response to treatment and screening prognosis.

Although we did not have the opportunity to perform a full assessment in this study, in order for lactate to increase secondary to HS and for lactic acidosis to develop, anaerobic metabolism has to replace aerobic metabolism, and lactate must emerge as the resulting end product. This is a multistage process, and relatively more advanced stages of HS or longer exposure to this ischemic-hypoxic state will be required in order for it to occur and for high lactate levels to be capable of being determined in blood. Serum albumin is the most abundant protein in human blood. Albumin, which plays an important role in the regulation of oncotic pressure, also serves as a buffer in the regulation of blood $\mathrm{pH}$. Studies have shown that albumin undergoes modification within minutes in ischemic-hypoxic states. ${ }^{[1]}$ From that perspective, HS-related increases in IMA and IMAR may be expected to appear before an increase in lactate and before blood becomes acidotic, and these increases may be expected to be detected earlier, and in milder cases of HS. This is a subject that definitely requires investigation. Our study, to our knowledge, the first to assess IMA and IMAR values in HS cases, is not capable of solving all these questions that need to be answered and that will contribute to the management of HS. However, it will serve as a guide to future studies on this subject.

\section{Limitations}

The main limitation of our study is that although the experimental protocol was scrupulously applied and no additional procedure was performed in the sham groups other than anesthesia and femoral artery cannulation, some degree of damage appears to have developed in almost all organs. This damage is probably associated with the anesthesia administered or with surgical stress.

Although similar experimental procedures were applied in the control groups and the shock groups, it should not be forgotten that this damage might have affected serum IMA and lactate levels, and the IMAR values calculated.
Second, of the various biomarkers recommended by current trauma management guidelines in the diagnosis and management of HS, only lactate was used for comparison in this study. Blood gas measurements were not performed, and other parameters recommended by the ATLS in the diagnosis and management of $\mathrm{HS}$, such as $\mathrm{pH}$ and base deficit, was not evaluated. Our research was an experimental study planned to simulate HS. Two subgroups, mild and severe HS, were established based on decreases in MAP, for that simulation. This shock severity scoring performed solely on the basis of a decrease in MAP does not exactly reflect the four-stage classification based on physiological parameters and used in clinical practice.

\section{Conclusion}

Our study findings suggest that IMA and IMAR values follow a similar course to those of lactate, which is still used in the diagnosis and management of HS. From that perspective, IMA and IMAR values have the potential to be used in the early diagnosis of HS and as a prognostic marker. IMA and IMAR measurement may be considered in the early diagnosis of HS as an alternative to lactate under conditions affecting lactate levels.

Ethics Committee Approval: Approved by the local ethics committee.

Peer-review: Internally peer-reviewed.

Authorship Contributions: S.T., A.S., M.Y., E.Y., A.M.: substantial contributions to conception and design, experimentation, acquisition of data, analysis and interpretation of data, drafting the article or revising it critically for important intellectual content and final approval of the version to be published; M.A., S.D., G.D.R.K., Sh.T., S.A.: Experimentation, acquisition of data, interpretation of data, drafting the article or revising it critically for important intellectual content and final approval of the version to be published (ST*: Suha Turkmen).

Conflict of Interest: None declared.

Financial Disclosure: This study was supported by the scientific and technical research fund of Karadeniz Technical University (THD-20I5-5306).

\section{REFERENCES}

1. Musalar E, Ersel M, Akarca FK, Kiyan GS, Can Ö. The predictive value of biochemical parameters in evaluating patients with abdominal trauma: The new scoring system. Turk J Emerg Med 2017;17:48-55. [CrossRef]

2. Tran A, Matar M, Lampron J, Steyerberg E, Taljaard M, Vaillancourt C. Early identification of patients requiring massive transfusion, embolization or hemostatic surgery for traumatic hemorrhage: A systematic review and meta-analysis. J Trauma Acute Care Surg 2018;84:505-16.

3. ATLS Subcommittee; American College of Surgeons' Committee on Trauma; International ATLS working group. Advanced trauma life support $\left(\mathrm{ATLS}^{\oplus}\right)$ : the ninth edition. J Trauma Acute Care Surg 2013;74:1363-6. [CrossRef]

4. Bruijns SR, Guly HR, Bouamra O, Lecky F, Lee WA. The value of tra- 
ditional vital signs, shock index, and age-based markers in predicting trauma mortality.J Trauma Acute Care Surg 2013;74:1432-7. [CrossRef]

5. Schiller AM, Howard JT, Convertino VA. The physiology of blood loss and shock: New insights from a human laboratory model of hemorrhage. Exp Biol Med (Maywood) 2017;242:874-83. [CrossRef]

6. Johnson MC, Alarhayem A, Convertino V, Carter R 3rd, Chung K, Stewart $\mathrm{R}$, et al. Comparison of compensatory reserve and arterial lactate as markers of shock and resuscitation. J Trauma Acute Care Surg 2017;83:603-8. [CrossRef]

7. Sarıydın T, Çorbacıoğlu ŞK, Çevik Y, Emektar E. Effect of initial lactate level on short-term survival in patients with out-of-hospital cardiac arrest. Turk J Emerg Med 2017;17:123-7. [CrossRef]

8. Turedi S, Yilmaz SE, Mentese A, Turkmen S, Karaca Y, Sen O, et al. The diagnostic value of serum ischemia-modified albumin levels in experimentally induced carbon monoxide poisoning and their correlation with poisoning severity. Acad Emerg Med 2013;20:652-8. [CrossRef]

9. Türedi S, Karahan SC, Menteşe A, Gündüz A, Topbaş M, Koşucu P, et al. Investigation of relationship between the $\mathrm{D}$-dimer and ischemiamodified albumin levels with the radiological imaging-based pulmonary embolism severity score in acute pulmonary embolism. Anadolu Kardiyol Derg 2010;10:346-52. [CrossRef]

10. Turedi S, Gunduz A, Mentese A, Dasdibi B, Karahan SC, Sahin A, et al. Investigation of the possibility of using ischemia-modified albumin as a novel and early prognostic marker in cardiac arrest patients after cardiopulmonary resuscitation. Resuscitation 2009;80:994-9. [CrossRef]

11. Gunduz A, Turkmen S, Turedi S, Mentese A, Yulug E, Ulusoy H, et al. Time-dependent variations in ischemia-modified albumin levels in mesenteric ischemia. Acad Emerg Med 2009;16:539-43. [CrossRef]

12. Lu YQ, Cai XJ, Gu LH, Wang Q, Huang WD, Bao DG. Experimental study of controlled fluid resuscitation in the treatment of severe and uncontrolled hemorrhagic shock. J Trauma 2007;63:798-804. [CrossRef]

13. Lee JH, Kim K, Jo YH, Kim MA, Lee KB, Rhee JE, et al. Blood pressuretargeted stepwise resuscitation for hemorrhagic shock in rats. J Trauma Acute Care Surg 2014;76:771-8. [CrossRef]

14. Takasu A, Prueckner S, Tisherman SA, Stezoski SW, Stezoski J, Safar P. Effects of increased oxygen breathing in a volume controlled hemorrhagic shock outcome model in rats. Resuscitation 2000;45:209-20. [CrossRef]

15. Erel $\mathrm{O}$. A novel automated method to measure total antioxidant response against potent free radical reactions. Clin Biochem 2004;37:112-19.

16. Erel $\mathrm{O}$. A new automated colorimetric method for measuring total oxidant status. Clin Biochem 2005;38:1103-11. [CrossRef]

17. Tokatli F, Uzal C, Doganay L, Kocak Z, Kaya M, Ture M, et al. The po- tential cardioprotective effects of amifostine in irradiated rats. Int J Radiat Oncol Biol Phys 2004;58:1228-34. [CrossRef]

18. Karahan SC, Türkmen S, Menteşe A, Zengin A, Gündüz A, Türedi $\mathrm{S}$, et al. Ischemia-modified albumin as an early diagnostic marker for acute renal ischemia and infarction. Turkiye Klinikleri J Med Sci 2010;30:1230-5. [CrossRef]

19. Yildız O, Can Z, Saral O, Yuluğ E, Oztürk F, Aliyazıcıoğlu R, et al. Hepatoprotective potential of chestnut bee pollen on carbon tetrachloride-induced hepatic damages in rats. Evid Based Complement Alternat Med 2013;2013:461478. [CrossRef]

20. Erkanli K, Kayalar N, Erkanli G, Ercan F, Sener G, Kirali K. Melatonin protects against ischemia/reperfusion injury in skeletal muscle. J Pineal Res 2005;39:238-42. [CrossRef]

21. Furmaga W, Cohn S, Prihoda TJ, Muir MT, Mikhailov V, McCarthy J, et al. Novel markers predict death and organ failure following hemorrhagic shock. Clin Chim Acta 2015;440:87-92. [CrossRef]

22. Meregalli A, Oliveira RP, Friedman G. Occult hypoperfusion is associated with increased mortality in hemodynamically stable, high-risk, surgical patients. Crit Care 2004;8:R60-5. [CrossRef]

23. Baxter J, Cranfield KR, Clark G, Harris T, Bloom B, Gray AJ. Do lactate levels in the emergency department predict outcome in adult trauma patients? A systematic review. J Trauma Acute Care Surg 2016;81:555-66.

24. Batra P, Dwivedi AK, Thakur N. Bedside ABG, electrolytes, lactate and procalcitonin in emergency pediatrics. Int J Crit Illn Inj Sci 2014;4:24752. [CrossRef]

25. Choi SB, Park JS, Chung JW, Kim SW, Kim DW. Prediction of ATLS hypovolemic shock class in rats using the perfusion index and lactate concentration. Shock 2015;43:361-8. [CrossRef]

26. Soller B, Zou F, Prince MD, Dubick MA, Sondeen JL. Comparison of Noninvasive $\mathrm{pH}$ and Blood Lactate as Predictors of Mortality in a Swine Hemorrhagic Shock with Restricted Volume Resuscitation Model. Shock 2015;44:90-5. [CrossRef]

27. Saad S, Mohamed N, Moghazy A, Ellabban G, El-Kamash S. Venous glucose, serum lactate and base deficit as biochemical predictors of mortality in patients with polytrauma. Ulus Travma Acil Cerrahi Derg 2016;22:29-33. [CrossRef]

28. Andersen LW, Mackenhauer J, Roberts JC, Berg KM, Cocchi MN, Donnino MW. Etiology and therapeutic approach to elevated lactate levels. Mayo Clin Proc 2013;88:1127-40. [CrossRef]

29. Cakir M, Karahan SC, Mentese A, Sag E, Cobanoglu U, Polat TB, et al. Ischemia-modified albumin levels in children with chronic liver disease. Gut Liver 2012;6:92-7. [CrossRef] 


\section{Hemorajik şok tanısında ve evrelemesinde iskemi modifiye albümin ve IMA/albümin oranı: Randomize kontrollü deneysel çalışma}

\section{Dr. Süleyman Türedi, ${ }^{1}$ Dr. Aynur Şahin, ${ }^{1}$ Dr. Metehan Akça, ${ }^{2}$ Dr. Selim Demir, ${ }^{3}$ Dr. Gökçen Derya Reis Köse, ${ }^{4}$ Dr. Arif Burak Çekiç, ${ }^{5}$ Dr. Mehmet Yıldırım, ${ }^{2}$ Dr. Ersin Yuluğ ${ }^{4}$ Dr. Ahmet Menteşe, ${ }^{6}$ Dr. Süha Türkmen, ${ }^{7}$ Dr. Sami Acar ${ }^{8}$}

${ }^{1}$ Karadeniz Teknik Üniversitesi Tıp Fakültesi, Acil Tıp Anabilim Dalı, Trabzon

${ }^{2}$ Sağlık Bilimleri Üniversitesi Tıp Fakültesi, Fizyoloji Anabilim Dalı, İstanbul

${ }^{3}$ Karadeniz Teknik Üniversitesi Sağlık Bilimleri Fakültesi, Beslenme ve Dieyetetik Bölümü, Trabzon

${ }^{4}$ Karadeniz Teknik Üniversitesi Tıp Fakültesi, Histoloji Anabilim Dalı, Trabzon

${ }^{5}$ Karadeniz Teknik Üniversitesi Tıp Fakültesi, Genel Cerrahi Anabilim Dalı, Trabzon

${ }^{6}$ Karadeniz Teknik Üniversitesi Sağlık Bilimleri Fakültesi, Medikal Laboratuvar Teknikleri Bölümü, Trabzon

${ }^{7}$ Acıbadem Üniversitesi, Tıp Fakültesi Acil Tıp Anabilim Dalı, İstanbul

${ }^{8}$ Acıbadem Üniversitesi Tıp Fakültesi, Genel Cerrahi Anabilim Dalı, İstanbul

AMAÇ: Hemorajik şokun (HS) tanı ve evrelemesinde iskemi modifiye albümin (IMA) ve IMA/albümin oranının (IMAR) değerini belirlemek.

GEREÇ VE YÖNTEM: Basınç hedefli bir HS modeli oluşturuldu. Kontrol ve şok grupları, HS'ye çeşitli maruz kalma sürelerini simüle etmek için 30 dakika ve 60 dakika boyunca izlendi. Deneyler sırasında tüm deneklere invaziv arter muayenesi yapıldı ve ayrıca ortalama arter basıncı (MAP) azalışlarına dayanarak hafif ve şiddetli şok gruplarına ayrıldı. Gruplar arasında biyokimyasal ve histolojik karşılaştırmalar yapıldı.

BULGULAR: Sonuçlarımız kontrol grubuna göre hem 30 hem de 60 dakikalık şok gruplarında IMA, IMAR, laktat, total oksidan durumu (TOS), total antioksidan durumu (TAS) ve oksidatif stres indeksi (OSI) düzeylerini ortaya koydu. MAP bazlı şok evrelemesi açısından, 30 dakikalık ve 60 dakikalık hafif ve şiddetli şok gruplarındaki IMA, IMAR, laktat, TOS ve OSI düzeyleri kontrol grubundan daha yüksekti. Ancak, hafif ve şiddetli şok grupları arasında anlamlı fark yoktu. Değerlendirilen tüm biyobelirteçler ile çeşitli organlarda HS kaynaklı hasar arasında anlamlı korelasyon tespit edildi. Bu korelasyon laktat ve IMAR düzeylerinde en yüksekti.

TARTIŞMA: İskemi modifiye albumin ve IMAR düzeyleri HS'nin erken tanısında kullanılabilir ve ayrıca HS'nin şiddetini belirlemede kullanım potansiyeline sahiptir. IMA ve IMAR ölçümü alternatif olarak veya HS tanısında laktat ölçümüne ek olarak düşünülebilir.

Anahtar sözcükler: Albümin; hemoraji; hemorajik şok; iskemi modifiye albümin; laktat; travma.

Ulus Travma Acil Cerrahi Derg 2020;26(2):I53-I62 doi: 10.14744/tjtes.2019.32754 